\title{
Agnieszka Nogal
}

\section{Solidarność \\ jako wartość polityczna \\ DOI 10.35757/CIV.2013.15.05}

Słowo solidarność kojarzy się wszystkim $z$ najnowszą historią Polski. Przywołuje bowiem fenomen ruchu społecznego $z$ roku 1980, związanego $z$ żądaniem legalizacji Niezależnego Samorządnego Zwiazku Zawodowego ${ }^{1}$. W niniejszym tekście zostanie jednak przeanalizowany inny wymiar idei solidarności - jej znaczenie jako wartości politycznej. Będzie nas przy tym interesowało znaczenie solidarności jako wartości politycznej, która może stabilizować wspólnotę polityczna. W kontekście rewolucji znaczenie solidarności jest niejednoznaczne. Solidarność pojawiła się bowiem w słowniku haseł politycznych wraz $z$ rewolucja francuska - obok wolności, równości oraz braterstwa - zarazem jednak w wielu analizach filozoficzno-politycznych solidarność traktuje się jako remedium na ruchy rewolucyjne.

Kontekst tych rozważań wyznacza współczesność, w której konflikty społeczne coraz częściej sięgają po język ekonomii. Solidarność w wymiarze ekonomicznym sprzyja usuwaniu nierówności społecznych. W tym sensie solidarność oznacza dążenie do „spłaszczania” nierówności oraz przekonanie, iż wspólnota polityczna, w której

Agnieszka Nogal - doktor habilitowany, pracuje w Zakładzie Filozofii Polityki Instytutu Filozofii Uniwersytetu Warszawskiego.

1 Główne prace poświęcone historii ruchu społecznego Solidarność to: A. Touraine: Solidarność. Analiza ruchu społecznego 1980-1981, przekład J. Strzelecki, F. Dubet, M. Wieviora, Europejskie Centrum Solidarności, Gdańsk 2010; J. Staniszkis: Samoograniczajaca sie rewolucja, przekład M. Szopski, Europejskie Centrum Solidarności, Gdańsk 2010; D. Ost: Klęska "Solidarności». Gniew i polityka w postkomunistycznej Europie, przekład H. Jankowska, Muza, Warszawa 2007. 
dominuje średnia własność, a różnice ekonomiczne nie sa zbyt głębokie, wykazuje mniejsze skłonności rewolucyjne. Ruchy takie jak Occupy Wall Street czy Oburzeni w Europie wyrażaja bunt przeciw nierównościom i wyzyskowi oraz narastajacemu ekonomicznemu rozwarstwieniu społecznemu. Młodzi żądaja od bogatych solidarności $z$ ubogimi, solidarności niełatwej do wyrażenia $\mathrm{w}$ języku liberalizmu, w którym sukces jednostki odzwierciedla jedynie jej indywidualna zasługę. Taka solidarność jest także trudno uchwytna w marksizmie, w którym sprowadza się co najwyżej do solidarności klasowej, solidarności biednych przeciw bogatym. W tej sytuacji warto sięgnąc po narzędzia, jakie daje filozofia polityki, aby przyjrzeć się nieco idei solidarności oraz jej ewentualnym zastosowaniom. Coraz częściej bowiem solidarność staje się hasłem politycznym w obrębie wspólnoty oraz w skali globalnej. Ponadto jest to idea, która ma także swoiście polski kontekst.

Polska Solidarność wprawdzie stanowiła nie tyle realizację jakiejś idei, ile ruch społeczny, który cechowała ogólnonarodowa mobilizacja. Niemniej przyczyniła się ona do wprowadzenia pojęcia solidarność na stałe do debaty społeczno-politycznej. Polacy, jako jedyne społeczeństwo świata komunistycznego, w latach siedemdziesiatych XX wieku, rozwinęli coś w rodzaju niezależnego społeczeństwa obywatelskiego, które samoorganizowało się przeciw oficjalnym strukturom państwa ${ }^{2}$. W tym znaczeniu solidarność niosła niewatpliwie ładunek rewolucyjny. Związek idei solidarności $z$ historycznym antysystemowym ruchem społecznym w Polsce jest więc oczywisty, warto jednak zwrócić uwagę także na inne wymiary tej idei. Dochodzimy bowiem do trzech znaczeń pojęcia solidarności: jako konkretnego historycznego ruchu społecznego, jako postulatu politycznego oraz jako idei filozoficznej. W niniejszym tekście skupię się na trzecim $z$ wyróżnionych znaczeń, traktując solidarność przede wszystkim jako ideę filozoficzną, mająca

\footnotetext{
${ }_{2}^{2}$ K. Kumar: Społeczeństwo obywatelskie. Rozważania na temat użyteczności historycznego terminu, w: J. Szacki (red.): Ani ksią̇ę, ani kupiec: obywatel. Idea społeczeństwa obywatelskiego $w$ myśli współczesnej, przekład B. Szacka, A. Szymanowski, E. Woydyłło, Instytut Wydawniczy Znak - Fundacja im. Stefana Batorego, Kraków 1997, s. 314.
} 
dla polityki znaczenie normatywne, a więc wyznaczające pewne normy wskazujące, jak powinno się działać w polityce.

Teza tego tekstu jest twierdzenie, iż solidarność $z$ perspektywy filozofii polityki, choć może zawierać ładunek rewolucyjny, może też spełniać funkcję wartości stabilizującej wspólnotę polityczną. Dzieje się tak, gdy solidarność spaja społeczeństwo, jednoczy, niwelując antagonizmy. Solidarność ma charakter rewolucyjny wówczas, gdy konsoliduje społeczeństwo. Sama idea solidarności pozwala jednak przyjrzeć się rewolucji jako idei jej przeciwstawnej, antonimicznej. Solidarna wspólnota polityczna, będąc niepodzielona, nieporóżniona, nie jest bowiem skłonna do obalania władzy, gdyż nie nastawia społeczeństwa przeciwko niej.

Idea solidarności pojęta jako przeciwieństwo rewolucji pozwala poprowadzić nasze rozważania w wielu kierunkach, ukazując różne konteksty jej funkcjonowania, solidarność bowiem można ująć jako: 1) określona postawę wobec przeszłości oraz pamięci, 2) pewna ideę etyczna ${ }^{3}$, 3) stosunek do wspólnoty losu i wspólnoty egzystencji, 4) wartość ekonomiczną. Tematem niniejszego tekstu będzie jedynie ekonomiczny wymiar solidarności politycznej. Solidarność jednoczy społeczeństwo i ma charakter antyrewolucyjny. Tak tę zależność postrzegali już filozofowie klasyczni: Platon i Arystoteles, tak widza ja współcześni socjologowie, jak chociażby Robert Putnam, tak funkcjonuje w wyobraźni społecznej, przywołując obrazy solidarnych działań i zachowań. Fakt, że solidarność ekonomiczna można postrzegać jako wartość polityczną zostanie przedstawiony w trzech płaszczyznach: historyczno-pojęciowej, analitycznej i normatywnej. Ponadto niniejszym rozważaniom towarzyszy przekonanie, iż deliberacje na temat normatywnych wymiarów polityki w naturalny sposób sięgają po myśl klasyków, mając ją nie tyle za gotowy przepis, ile za inspirację dla współczesnych badań, w których pewne normy znajduja zastosowanie

\footnotetext{
${ }^{3}$ „Doświadczenie "pierwszej Solidarności» to doświadczenie wspólnoty tych wszystkich, którzy dostrzegli, że można żyć zgodnie $z$ sumieniem i postanowili tak właśnie żyć”. Z. Stawrowski: Solidarność znaczy więź, w: idem: Solidarność znaczy więź. W kręgu myśli Józefa Tischnera i Jana Pawła II, Instytut Myśli Józefa Tischnera, Kraków 2010, s. 111.
} 
w zupełnie innym, radykalnie przekształconym kontekście. Celem takich analiz nie jest ukazywanie rozwiązań praktycznych, ale raczej studium nad językiem debaty publicznej i politycznej. Spróbujmy zatem się przyjrzeć, czy idea solidarności może się okazać nadal dyskursywnie owocna.

Już Platon i Arystoteles, a więc autorzy źródłowi dla filozofii polityki, zastanawiali się, jak urządzić państwo, aby uzyskało ono stabilność. Wprawdzie wówczas nie posługiwali się terminem solidarność, ale zauważyli, że o wstrząsach politycznych, które nazywali stasis, decydowały różnice $\mathrm{w}$ stanie posiadania obywateli. Najostrzej widział ten problem Platon, on też sięgał po najsurowsze rozwiązania. Sprzeczność interesów między biednymi i bogatymi chciał rozwiazać, pozbawiając obywateli własności prywatnej i czyniąc $z$ niej własność wspólną. Arystoteles, mimo że nie był aż tak radykalny, również proponował swego rodzaju ekonomiczna równość. I to jego rozwiązanie można dziś postrzegać jako źródło idei solidarności, choć sam termin narodził się wieki później.

Solidarność jest bowiem pojęciem nowożytnym, choć ma starożytne, łacińskie źródła. W rzymskim języku prawniczym odnosi się ono do współodpowiedzialności za rzecz lub świadczenie. Rzymskie pojęcie in solidum oznacza obowiazek dla wszystkich (obligation in solidum). Odpowiedzialność tego typu to sytuacja, w której na przykład dłużnicy są zobowiązani wypełnić na rzecz tego samego wierzyciela identyczne świadczenie $z$ takim skutkiem, że wypełnienie owego świadczenia przez jednego $z$ nich zwalnia pozostałych. Można zatem stwierdzić, że przy odpowiedzialności solidarnej każdy odpowiada za wszystkich pozostałych, a los wspólników zależy od wypłacalności najsłabszego $z$ nich. I choć jako hasło polityczne solidarność pojawiła się dopiero w czasach rewolucji francuskiej, kiedy to oznaczała właśnie współodpowiedzialność za najsłabszy, pozbawiony wcześniej prawa głosu stan trzeci, to sama idea wsparcia najsłabszych obywateli we wspólnocie politycznej istniała znacznie wcześniej. Narodziła się wraz z pracami klasyków filozofii politycznej. Projekt zrównywania nierówności 
ekonomicznych, znoszenia sprzeczności interesów jest zatem równie wiekowy jak sama filozofia polityki.

Wolno wręcz przyjać, że cel takich dzieł jak Państwo Platona i Polityka Arystotelesa sprowadzał się do zapobieżenia wstrząsom politycznym, czyli stasis. Owe stasis pozostawały w tle rozważań obu filozofów jako negatywny układ odniesienia. O ile jednak Platon szukał źródła stabilności sytuacji politycznej w odejściu od własności prywatnej, o tyle Arystoteles wprowadził po raz pierwszy projekt „solidarnościowy”. Rozwiązanie Platona miało charakter niezwykle radykalny, jako że za jedno ze źródeł zamieszek uznał on własność prywatna. Zaproponował więc, aby wprowadzająca konflikty interesów własność prywatna zastąici własnością wspólną: „Po pierwsze żaden $z$ nich [rządzących obywateli - przyp. A.N.] nie powinien mieć żadnego osobistego majatku, chyba że niezbędną konieczność. Po drugie, domu i spichrza nie powinien żaden $z$ nich mieć ani żadnego takiego pomieszczenia, do którego by nie mógł wejść każdy, kto by chciał. [...] A będą się stołowali we wspólnym lokalu, jak na wyprawie wojennej, i będa żyli wspólnie"4.

Zdaniem Arystotelesa natomiast źródłem konfliktów społecznych i rozruchów politycznych jest nie tyle własność prywatna, ile znaczące różnice we własności. To jego, jak się wydaje, można uznać za protoplastę uznania solidarności, zwłaszcza w wymiarze ekonomicznym, za istotną wartość polityczna.. Jak już zostało powiedziane, Arystoteles nie mówił jeszcze o solidarności, ale jednym $z$ głównych celów dobrego ustroju uczynił znoszenie nadmiernych nierówności ekonomicznych. Nie opowiadał się zatem za odebraniem obywatelom ich prywatnej własności, lecz za swoistym „spłaszczeniem” różnic ekonomicznych, czyli doprowadzeniem do sytuacji, w której dobrostan polis wiąże się, po pierwsze, $z$ dobrostanem każdego obywatela, a po drugie $-z$ sytuacja, w której system polityczny zakłada brak znaczacych różnic ekonomicznych. Stagirytę interesowały zwłaszcza dysproporcje mię-

4 Platon: Państwo, ks. III, XXII, t. I, przekład W. Witwicki, Wydawnictwo Alfa, Warszawa 1994, s. 162. 
dzy dwiema najbardziej antagonistycznymi grupami społecznymi: grupa bardzo bogatych oraz biedota. Napięcia między nimi prowadza, jego zdaniem, do zamieszek politycznych i zmian ustroju. Można powiedzieć, że, w ujęciu tego filozofa, zarówno bogacze, jak i biedota, przy znacznych dysproporcjach między nimi, to dwie grupy zdolne do przewrotu ${ }^{5}$. Doprowadzaja one bowiem do zmian ustrojowych, które zawsze wiązały się ze wstrząsami społecznymi. Stabilizująca rolę dla życia społecznego odgrywa natomiast grupa obywateli posiadajacych średnią własność - im jest ona liczniejsza, tym trwalszy będzie, wedle Arystotelesa, porzadek polityczny. Wzrastająca dysproporcja zaś między bogatymi i biedota prowadzi do zaburzeń tego ładu.

Stasis, w najprostszym ujęciu, to dążenie do zmiany ustroju. Arystotelesowi zawdzięczamy klasyczny podział ustrojów politycznych na trzy właściwe: monarchię, arystokrację, politeję oraz trzy zdegenerowane: tyranię, oligarchię, demokrację. I tak jak w każdym społeczeństwie polis można wyróżnić dwie podstawowe grupy: biednych i bogatych, tak samo da się wskazać dwa podstawowe ustroje, w zależności od tego, która $z$ tych grup ma przewagę. Sa to, zdaniem Arystotelesa, demokracja opierajaca się na władzy ubogich oraz oligarchia, w której władza jest w rękach bogatych: „Dlatego też głównie ustroje powstają: demokracja i oligarchia; szlachectwo bowiem i cnota jest udziałem niewielu, natomiast to [co stanowi podstawę obu tych ustrojów] częściej się spotyka. Bo ludzi szlachetnego rodu i cnotliwych nigdzie i setki nie ma, a bogatych [jak i ubogich] wielu wszędzie bywa"

Chociaż Arystoteles w V księdze Polityki wymienił wiele przyczyn zamieszek politycznych, to można uznać, że wszystkie rewolucje, jego zdaniem, rodzą się $z$ nierówności. Stagirycie zawdzięczamy wnikliwa analizę zjawiska nierówności jako źródła stasis. Uznaje on, że rewolucyjny nastrój umysłu wypływa $z$ jednostronnego poj-

\footnotetext{
${ }_{5}$ Pojęcie rewolucji zostanie nieco obszerniej wyjaśnione później. Tu używane jest metaforycznie, jako określenie zmiany ustroju, a więc stasis.

6 Arystoteles: Polityka, w: idem: Dzieła wszystkie, t. VI, przekład L. Piotrowicz, Wydawnictwo Naukowe PWN, Warszawa 2001, s. 136.
} 
mowania równości. Demokraci sądzą, że ludzie, którzy są w równy sposób wolni, powinni mieć taki sam udział we władzy. Oligarchowie uważają natomiast, że tylko ludzie mający równie duże majątki powinni mieć proporcjonalny do tych majątków udział we władzy. Dążenie do rozmaicie pojmowanej równości oraz sprawiedliwości staje się zatem, według Arystotelesa, główna przyczyną wstrząsów politycznych: „W oligarchiach, jak to już poprzednio powiedziano, porywaja się do powstania masy, które odczuwaja to jako krzywdę, że nie posiadaja praw równych, mimo że sa równe innym, natomiast $\mathrm{w}$ demokracjach czynią to możni obywatele, ponieważ przysługuja im tylko równe prawa, chociaż wyrastaja ponad równość”’.

Jak wyżej wspomniano, zdaniem Arystotelesa, biedni i bogaci stanowia dwie główne grupy zamieszkujące polis, będące zarazem grupami zdolnymi do przewrotu. Dzieje się tak, ponieważ, w jego przekonaniu, grupy te charakteryzuje sprzeczność interesów ich przedstawicieli. Przy sprzeczności interesów każda $z$ nich dąży do dominacji nad drugą, gdyż obie dążą do przejęcia władzy. Bogaci pragna oligarchii, a więc władzy sprawowanej wyłącznie przez najbogatszych, biedni natomiast - demokracji, czyli władzy sprawowanej przez biednych. W oligarchii jedynie najbogatsi maja zarówno ziemie, jak i władzę, której używają, bogacąc się jeszcze bardziej kosztem biedoty, w demokracji - większość biednych posiada władzę i wykorzystuje ja przeciwko bogatym. Przy tym żaden $z$ tych ustrojów nie wykazuje, zdaniem Arystotelesa, trwałości, gdyż naruszając zbiorowy interes grupy przeciwnej, doprowadza do jej konsolidacji oraz buntu. Nie zawsze wprawdzie dochodzi od razu do rozruchów, ale zarówno oligarchia, jak i demokracja aktywizują stronę przeciwną. Zamieszki zaś powstają wówczas, gdy żadna ze stron nie ma zdecydowanej przewagi. „Przewroty ustrojowe - pisze autor Polityki - następuja również wówczas, gdy klasy obywateli uchodzace za przeciwstawne, jak na przykład bogaci i lud, utrzymują się w równowadze, a stan pośredni

7 Ibidem, s. 140. 
nie istnieje albo też znikomą gra rolę. Bo jeśli jedna $z$ tych klas znaczna wykazuje przewage, to druga nie zechce podjać niebezpiecznej walki przeciw wyraźnie silniejszej"8.

Równowagę w społeczności polis zapewnia, zdaniem Arystotelesa, dopiero silna klasa średnia i oparta na jej władzy politeja. Czym miałaby się charakteryzować owa klasa średnia, dowiadujemy się z normatywnej części koncepcji Stagiryty, gdy kreśli on wizję idealnej polis. Otóż polis, w jego przekonaniu, byłaby stabilna dopiero wówczas, gdyby składała się $z$ samodzielnych posiadaczy, których własność byłaby równa. Arystoteles odrzuca tym samym koncepcję Platona, jakoby rezygnacja $z$ własności prywatnej na rzecz własności wspólnej miała zapewnić stabilność polis. Uznaje jednak, że znaczące różnice ekonomiczne rozbijaja polis i dlatego należałoby obywateli idealnej polis zrównać pod względem ekonomicznym.

W VII księdze Polityki (pkt 9) Arystoteles stwierdził, że równość sytuacji ekonomicznej obywateli stanowi jeden $z$ warunków najlepszej polis i zaproponował podział ziemi na równe działki gruntu. Własność ziemska powinni posiadać tylko obywatele, ale zarazem każdy dzięki niej powinien osiagnąć samodzielność ekonomiczną: „Wypowiedziałem się już przedtem przeciw temu, by własność ziemska była wspólna, jak to niektórzy głosili, bo zajmuję to stanowisko, że winna ona stawać się niejako wspólną przez przyjacielskie zużytkowanie, zarazem jednak jestem zdania, że żadnemu obywatelowi nie powinno zabraknać tego, co mu do

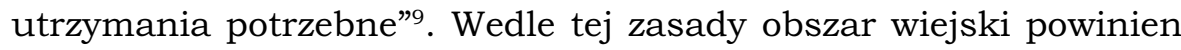
być podzielony na dwie części: wspólna i prywatną. $Z$ części wspólnej jedna powinno się przeznaczyć na potrzeby kultu, druga na wspólne biesiady. W części prywatnej każdy miałby jedną działkę blisko miasta, a druga - przy granicy, aby wszyscy obywatele byli $\mathrm{w}$ równym stopniu zainteresowani obrona polis. Posiadanie ziemi nie oznacza, według Arystotelesa, obowiąku pracy na niej - na roli, zdaniem filozofa, powinni pracować niewolnicy. Na pry- 
watnych gruntach - prywatni, a na wspólnych - państwowi, istotne jednak jest przede wszystkim to, aby w najlepszej polis każdy obywatel posiadał taka samą własność ${ }^{10}$.

$\mathrm{W}$ ten sposób, prezentujac obraz idealnej polis, Arystoteles scharakteryzował klasę średnią. Stanowi ona nie tylko grupę pośrednia pomiędzy bogatymi a biednymi, ale przede wszystkim gromadzi obywateli niezależnych ekonomicznie od siebie nawzajem. Ta ekonomiczna niezależność staje się dopiero warunkiem sprawiedliwego udziału we władzy oraz przyjacielskich stosunków $z$ innymi. Zarówno bogaci, jak i biedni zależą od siebie nawzajem, lecz maja sprzeczne interesy. Dopiero istnienie klasy średniej - składającej się $z$ obywateli niezależnych ekonomicznie i sobie równych - nie tylko pod względem statusu obywatelskiego, ale także ekonomicznego - sprawia, że w idealnej polis realizuje się idea równości w duchu demokratycznym raczej niż oligarchicznym. Dlatego też Arystoteles uważał, że politeja, w której funkcję stabilizująca ustrój pełni klasa średnia, bliższa jest demokracji niż oligarchii. Pisał: „Także i politeja, opierająca się na średnim stanie, która jest najtrwalsza $z$ tego rodzaju ustrojów [czyli trwalsza zarówno od demokracji, jak i od oligarchii - przyp. A.N.], bliższa jest demokracji aniżeli oligarchii" ${ }^{11}$.

Z przytoczonych wyżej analiz można wyodrębnić następujące cechy obywateli przynależących do klasy średniej:

- posiadaja nieruchomości na obszarze polis - są więc właścicielami ziemskimi;

- maja czas, aby zajmować się polityką (praca w jej wymiarze ekonomicznym zajmuja się nieobywatele);

- są równi ekonomicznie, a więc konflikty ekonomiczne nie rozrywaja polis od wewnattrz;

- sa od siebie nawzajem niezależni, a zatem relacje obywatelskie nie sa zapośredniczone przez ekonomię i właściwe dla niej konflikty interesów.

10 Ibidem, s. 198.

11 Ibidem, s. 136. 
Na tym tle można także dokonać rekonstrukcji idei solidarności funkcjonującej w państwie, określając zarazem podstawowe cechy solidarnej wspólnoty politycznej. Otóż taka wspólnota opiera się na własności prywatnej (a nie wyłącznie wspólnej) oraz duże znaczenie przypisuje się $\mathrm{w}$ niej ekonomicznej niezależności obywateli, gdyż ma się świadomość zagrożeń zwiąanych $z$ wprowadzaniem do polityki zależności ekonomicznych i konfliktów interesów. $Z$ solidarnością wiąże się zatem pewna tendencja do usuwania nierówności, dzielenia własności w obrębie polis przez obarczenie największymi obowiązkami grupy najsilniejszej ekonomicznie oraz wsparcie grupy najmniej majętnej. $Z$ tego też powodu solidarność oznacza więź, która znajduje wyraz w rzymskiej instytucji prawnej in solidum. Tak jak solidarni dłużnicy zostaja ze sobą związani, gdyż każdy odpowiada za wszystkich pozostałych, a los wspólników zależy od wypłacalności najsłabszego $z$ nich, tak samo solidarna wspólnota polityczna to wspólnota, w której najsilniejsi ekonomicznie obywatele zostaja powiazani $z$ najsłabszymi, a los wspólnoty zależy od sytuacji jej najsłabszych członków. Wydaje się, że tak rozumiana solidarność polityczna na całe wieki została usunięta na dalszy plan publicznych debat, wypierana przez dwie konkurencyjne idee: ideę nieograniczonej własności prywatnej oraz, realizowany początkowo głównie we wspólnotach zakonnych, chrześcijański ideał własności wspólnej. Nigdy jednak idea solidarności nie zniknęła całkowicie.

Ciekawym przykładem żywotności idei solidarności jest choćby uznanie solidarności za wartość ogólnoludzką, i to przez filozofa uważanego powszechnie za prekursora liberalizmu - Johna Locke'a. Myśliciel ten, wskazując pochodzenie własności prywatnej, cytuje Księgę Psalmów i argumentuje, że sam Bóg „dał ziemię synom człowieczym we wspólne [podkreślenie - A.N.] władanie”12. W ten sposób ziemia i wszystkie dobra stały się współwłasnościa wszystkich ludzi. Dopiero przez pracę ludzie prawowicie zawłaszczyli elementy własności wspólnej. Niemniej to prawomocne

12 J. Locke: Dwa traktaty o rzadzie, przekład Z. Rau, Wydawnictwo Naukowe PWN, Warszawa 1992 , s. 180. 
zawłaszczanie miało też granice. Pozostawało prawomocne, o ile nie doprowadzało do nadmiernego gromadzenia i marnotrawstwa, jego granica było używanie zawłaszczonych przez pracę dóbr. To właśnie osobisty użytek, zdaniem Locke’a, powinien ograniczać własność prywatna, pozostawiając jak najwięcej współwłasności dla innych. Pisał on: „To samo prawo natury, które moca swoich postanowień nadaje nam własność, również ją ogranicza. Bóg nam wszystkiego obficie dostarcza do używania, I Tym 6,16, mówi nam Objawienie, umacniajac głos rozumu. Jak dalece On nam tego dostarcza? Do używania" [podkreślenie - A.N.] ${ }^{13}$.

Tymczasem dalszy rozwój myśli liberalnej odwoływał się raczej do prawomocności własności prywatnej niż do jej ograniczeń i tkwiącej u źródeł własności solidarności ogólnoludzkiej. W ten sposób myśl liberalna utraciła zdolność do mówienia o solidarności, która przywrócił dopiero w XX wieku John Rawls ${ }^{14}$.

Pojęcie solidarność, jak wyżej wspominano, znalazło się w obszarze debaty politycznej wraz $z$ rewolucja francuską. Przejęte $z$ języka prawniczego, w którym oznaczało wspólną odpowiedzialność za długi, zostało wprowadzone do koncepcji socjologicznych i politycznych. W czasie rewolucji zdarzało się, że w rewolucyjnym wezwaniu: Liberté, égalité, fraternité miejsce fraternité (braterstwa) zajmowała solidarité (solidarność). Mirabeau, przemawiając 28 października 1789 roku przed Narodowym Zgromadzeniem Ustawodawczym, wskazał na moralne znaczenie solidarności przekonań prywatnych i publicznych ${ }^{15}$. $Z$ kolei Danton 1 kwietnia 1793 roku stwierdził przed Konwentem Narodowym: „wszyscy jesteśmy solidarni dzięki identyczności naszych zachowań"16. W czasie rewolucji francuskiej powrócono więc do rzymskiej instytucji prawa cywilnego in solidum, która, w połączeniu $z$ republikańską ideą władzy

\footnotetext{
13 Ibidem, s. 184.

${ }^{14}$ Sam Rawls pisze wprawdzie, iż jego teoria sprawiedliwości wyraża ideę braterstwa, ale można ją opisać także przez pojęcie solidarności. Waskie ramy tekstu nie pozwalają na rekonstrukcję tej szerokiej i wpływowej koncepcji.

${ }^{15}$ H. Brunkhors: Solidarity. From Civic Friendship to a Global Legal Community, przekład

J. Flynn, The MIT Press, Cambridge, Mass. 2005.

${ }^{16}$ Ibidem.
} 
sprawowanej przez lud, zaowocowała idea solidarności ludu. Solidarność zaczęła więc oznaczać więź między obywatelami tej samej wspólnoty politycznej. Więź, która zobowiązywała wszystkich do wspierania najsłabszych. Co więcej, w jakobińskiej konstytucji z 24 czerwca 1793 roku znalazło się sformułowanie, iż krzywda wyrządzana któremukolwiek $z$ obywateli jest krzywda wyrządzona całemu ciału społecznemu oraz że krzywda wyrządzona całemu ciału społecznemu jest zarazem krzywda każdego $z$ obywateli ${ }^{17}$. W ten sposób pojęcie solidarność od razu nabrało podwójnego sensu: $z$ jednej strony oznaczało rewolucyjne hasło o charakterze burzycielskim, $z$ drugiej zaś - ideę zintegrowanego społeczeństwa jako celu rewolucji. Pojęcie to zatem od samego początku niosło ze soba $z$ jednej strony ideę, $z$ drugiej - postulat zmiany zastanego stanu. Ostatecznie jednak to element zmiany zdominowal konstruktywny wymiar rewolucyjnych haseł. Solidarność bowiem w XVIII wieku nie została opracowana pojęciowo, podczas gdy rewolucja była na ustach wszystkich - zarówno jej zwolenników, jak i przeciwników, wyznaczając nowoczesny model myślenia o polityce. Od tamtych czasów pojęcia te połączyły się ze sobą, czyniąc $z$ solidarności ideał rewolucyjny, przywoływany przez kolejnych rewolucyjnych filozofów, domagających się radykalnej zmiany rzeczywistości politycznej oraz społecznej.

Jeżeli zaś chodzi o pojęcie rewolucji, to ono także jest pojęciem nowożytnym. Ma wprawdzie źródła łacińskie, ale już $z$ okresu średniowiecza. We wczesnośredniowiecznej łacinie revolutio oznaczało cykliczność i powtarzalność zmian, serię sekwencji, przewidywalnych i urzeczywistniajacych określony, uprzedni ład. Revolutio oznaczało też „toczenie się do tyłu, powrót”, od łacińskiego revolvere - przewracać, obracać. W języku angielskim pojawiło się w 1390 roku, zapożyczone od starofrancuskiego revolution, i pierwotnie dotyczyło ruchu ciał niebieskich. Nowe znaczenie pojęcie to zawdzięcza publikacji dzieła Mikołaja Kopernika De revolutioni-

${ }_{17}$ Artykuł 34: „Il y a oppression contre le corps social lorsqu'un seul de ses membres est opprimé. Il y a oppression contre chaque membre lorsque le corps social est opprimé”. 
bus orbium coelestium (O obrotach sfer niebieskich), które w 1543 roku obalało cała oficjalną kosmologię. Odnosiło się wprawdzie do ruchu planet, ale wyznaczyło także radykalny zwrot w wyobrażeniach na temat wszechświata. Od tego czasu słowo rewolucja uzyskało wywrotowe konotacje i zaczęło oznaczać rewolucję naukowa. Na płaszczyźnie politycznej termin rewolucja zaczał funkcjonować dopiero w roku 1688, kiedy parlament angielski usuną $z$ tronu Jakuba II Stuarta i doprowadził do koronacji Wilhelma III Orańskiego, określając ten proces mianem glorious revolution, czyli chwalebnej (lub sławetnej) rewolucji.

Dla Thomasa Paine'a rewolucja amerykańska stanowiła jednak nadal odnowienie naturalnego porzadku rzeczy. W rewolucji amerykańskiej wierzono w kierunek rewolucyjnej zmiany, którym była realizacja naturalnego i racjonalnego porzadku, co $z$ konieczności wiązało się $z$ unicestwieniem porządku wynaturzonego i nieracjonalnego. Prawdziwa polityczna kariere słowo rewolucja zawdzięcza dopiero rewolucjom francuskiej i sowieckiej. W intuicyjnym ujęciu rewolucje te stanowia do dziś swoistą matrycę wydarzeń rewolucyjnych. Ciekawe, że ciagłość między rewolucjami francuska a sowiecka dostrzegali także inicjatorzy i przywódcy tej drugiej. Zarówno Karol Marks, jak i Fryderyk Engels byli przekonani, że rewolucja francuska nie zakończy się dopóty, dopóki nie zostaną osiągnięte jej cele społeczne ${ }^{18}$. Obie rewolucje łączy także pojęcie solidarności. O ile w trakcie rewolucji francuskiej pojawiało się ono sporadycznie i niosło ze sobą treść odpowiedzialności obywatelskiej za ogół, o tyle wraz $z$ rozwojem ruchów robotniczych nabierało ono coraz większego znaczenia. W rewolucji proletariackiej bowiem solidarność robotników przeciwko kapitalistom odegrała już pierwszoplanową rolę, tym samym zrywając zarówno $z$ rzymskim źródłem pojęcia solidarności, jakim była współodpowiedzialność za własność prywatna, jak i z republikańska idea ludu politycznego jako podstawy polityki.

${ }_{18}$ J. Baszkiewicz: Wolność, równość, własność. Rewolucje burżuazyjne, Czytelnik, Warszawa 1981 , s. 11. 
Paradoksalnie, mimo zwycięstwa rewolucji proletariackiej w Zwiąku Radzieckim, idea określającą europejski porządek w drugiej połowie XX wieku okazała się właśnie solidarność wewnątrz państwa narodowego. W okresie powojennym wszak $\mathrm{w}$ wielu państwach europejskich uruchomiono procesy jednoczesnego odbudowywania państwowości wraz rozszerzaniem roli opieki nad najsłabszymi. Bardzo ważnym czynnikiem sprzyjającym wówczas realizacji idei solidarności stała się ekonomia oraz redystrybucja dóbr zwiazana $z$ budową systemów zabezpieczeń społecznych. Wtedy także powstały teorie państwa opiekuńczego / państwa dobrobytu (welfare state). Źródeł tych koncepcji można poszukiwać w idei solidarności, rozumianej jako współodpowiedzialność za członków tej samej wspólnoty politycznej, choć niewątpliwie także znaczenie miały tu wpływy marksizmu. Realizacja tych ideałów skutecznie, jak się okazało, ustabilizowała systemy władzy w całej Europie Zachodniej aż do XXI wieku.

Również wśród współczesnych filozofów istnieją zwolennicy wiązania ekonomii $z$ polityka dzięki wyeksponowaniu znaczenia idei solidarności. Jednym $z$ nich jest Alasdair MacIntyre, który, wskazujac na negatywne konsekwencje dysproporcji ekonomicznych oraz konfliktów interesów, bierze pod uwage dwa elementy: pierwotne zawłaszczenie dóbr oraz konflikt interesów między bogatymi a biednymi.

Po pierwsze, pierwotne zawłaszczenie dóbr najczęściej bywa, jego zdaniem, niesprawiedliwe i grabieżcze. Jako przykład MacIntyre przywołuje obrazy używane przez goracego obrońcę wszelkiej własności, Edmunda Burke’a, który, opisując własność jako konieczną, naturalną, niepodważalną, posługiwał się takimi określeniami jak „prawowite dziedzictwo”, „rodzinny majatek” i używawał w swoich wywodach obrazów nagromadzonego dziedzictwa, bogactwa, ponadczasowej umowy jako czegoś, co reprodukuje porządek natury i nie pozwala się zanegować. Tymczasem, zdaniem MacIntyre'a, te obrazy Burke'a nie ukazywały faktycznego sposobu nabywania własności przez współczesnych Burke’a, ale raczej 
przesłaniały. Przez Anglię bowiem przetaczała się wówczas fala grabieży ziemi, będąca dziełem wielkich właścicieli ziemskich, której dokonywali oni w toku grodzenia ${ }^{19}$. W ten sposób sprzeczność interesów między tymi, którym ziemię odebrano a tymi, którzy się stali jej właścicielami została przykryta przez obrazy sankcjonujące prawowitość narracji tylko jednej ze stron. Akt dystrybucji własności nabrał $z$ tej perspektywy charakteru arbitralnego, gdyż był oparty na sile i hegemonii określonej grupy społecznej, wreszcie - na przypadku i zbiegach okoliczności. Pojawiające się zaś pojęcie ekwiwalentnej wymiany przesłoniło arbitralność tego, co było wobec wymiany uprzednie.

Ponadto, wedle MacIntyre'a, różnice między bogatymi a biednymi prowadzą do konfliktu interesów, który często uniemożliwia realizację wspólnego dobra. Argument ten MacIntyre wysunął wprost za Arystotelesem, wskazując, że tak jak w starożytnej polis różnice ekonomiczne rozrywały wspólnotę państwowa, tak samo rozrywaja ją i dziś. Zdaniem filozofa jedynie praktyka współdziałania wszystkich członków we względnie małych i lokalnych wspólnotach pozwala na harmonijne łączenie dobra indywidualnego $z$ dobrem zbiorowości, na zaangażowanie członków tych wspólnot w ochronę tego, co przejęte po poprzednikach ich osobistego uczestnictwa i refleksji. W retrospektywnym eseju zatytułowanym Trzy perspektywy na marksizm: 1953; 1968; 1995 MacIntyre przedstawia swe stanowisko następująco: „Formy praktyki społecznej we względnie małych i lokalnych wspólnotach - której przykłady obejmują niektóre starożytne miasta i niektóre średniowieczne komuny, a także pewne formy współczesnych spółdzielni rolniczych i rybackich - w których stosunki społeczne sa kształtowane za pomoca podzielanego wspólnego zaangażowania na rzecz dóbr wewnętrznych wobec praktyk wspólnotowych, dzięki czemu korzystanie $z$ władzy i bogactwa jest podporzadkowane osiaga-

\footnotetext{
${ }^{19}$ A. MacIntyre: Poezja jako filozofia polityczna. Uwagi na temat Burke'a $i$ Yeatsa, w: idem: Etyka i polityka, przekład J. Nalichowski, Wydawnictwo Naukowe PWN, Warszawa 2009, s. 245.
} 
niu tych dóbr racjonalnie i krytycznie, zamiast być zmuszonym do nieustannej walki, $z$ mniejszym lub większym powodzeniem, przeciwko redukcji do roli narzędzia takiego a nie innego sposobu akumulacji kapitału"20.

Warto przy tym podkreślić, że MacIntyre przemawia w obronie solidarności między obywatelami współodpowiedzialnymi za innych współobywateli. Nie chce likwidacji własności prywatnej, nie jest jednak również zwolennikiem nieograniczonej własności oraz bogacenia. $Z$ tego też powodu jako źródło stabilnego ładu politycznego wskazuje na lokalne wspólnoty, posiadające średni kapitał oraz związane bezpośrednimi kontaktami ich członków.

Ideał solidarności, od wieków atrakcyjny dla filozofów polityki, został poddany także badaniom socjologicznym. Socjolog Robert Putnam w słynnej pracy Demokracja $w$ działaniu, opartej na długoletnich analizach demokracji we Włoszech, stwierdził, iż relacje między mniej więcej równymi ekonomicznie obywatelami mają dla procesu budowy kultury demokratycznej znaczenie zasadnicze ${ }^{21}$. Takie odniesienia międzyobywatelskie pozbawione sa bowiem konfliktu interesów. Putnam nazywa je relacjami poziomymi i przeciwstawia relacjom pionowym patron-klient, które cechuja się znacznym zróżnicowaniem pozycji ekonomicznej stron. Opierając się na teorii gier wykazuje, że relacje między względnie równymi obywatelami sprzyjaja budowaniu więzi obywatelskich, które określa mianem kapitału społecznego: „Osobiste interakcje dostarczaja informacji o wiarygodności innych aktorów, co jest stosunkowo mało kosztowne i niezawodne. Jak przypomina nam ludowy teoremat $z$ teorii gier, istniejące zależności społeczne moga sprawić, że opłacalne będzie być godnym zaufania. Ponadto kontynuowane zależności często zostają wyposażone w społeczną treść, która każe wiązać wielkie oczekiwania $z$ zaufaniem i powstrzymywać się

\footnotetext{
${ }^{20}$ Idem: Trzy perspektywy na marksizm: 1953;1968;1995, w: Etyka i polityka, przekład J. Nalichowski, Wydawnictwo Naukowe PWN, Warszawa 2009, s. 234.

${ }^{21}$ R. Putnam: Demokracja $w$ działaniu. Tradycje obywatelskie we współczesnych Włoszech, przekład J. Szacki, Instytut Wydawniczy Znak - Fundacja im. Stefana Batorego, Kraków - Warszawa 1995.
} 
od oportunizmu [...]. Dylematy więźnia są [...] często omijane dzięki sile osobistych stosunków”22. Z kolei relacje między bogatymi i biednymi, które Putnam nazywa relacjami pionowymi, nie sprzyjaja budowie relacji obywatelskich. W relacjach pionowych grupa znacznie bogatszych ma skłonność do wykorzystywania biedniejszych, biedni natomiast wykazuja tendencję do pozorowania aktywności. Dzieje się tak w sferach zarówno pracy, jak i polityki. Putnam zauważał: „W pionowych stosunkach patron-klient, charakteryzujących się zależnością, a nie wzajemnością, oportunizm jest bardziej prawdopodobny zarówno wśród patronów (wykorzystywanie), jak i klientów (wymigiwanie się). Fakt, że zależności pionowe sa mniej przydatne w rozwiązywaniu problemów zbiorowego działania niż zależności poziome, może być jednym $z$ powodów większej sprawności kapitalizmu niż feudalizmu w XVIII wieku i większej sprawności demokracji niż autokracji w wieku XX"23.

Tak oto teza głosząca, iż solidarność $z$ perspektywy filozofii polityki może być postrzegana jako wartość, która stabilizuje wspólnotę polityczna, znajduje potwierdzenie $\mathrm{w}$ badaniach socjologicznych.

Więzi poziome, budujacc sieć wzajemnych relacji, spajają społeczeństwo, niwelując różnice wynikające $z$ innych źródeł. Solidarna wspólnota polityczna opiera się na własności prywatnej, a nie wyłącznie wspólnej, ale jednocześnie niweluje dysproporcje ekonomiczne, aby konflikty ekonomiczne nie stawały się treścią sporów politycznych, powodując powstawanie zantagonizowanych grup społecznych. Tak pojęta solidarność może stabilizować wspólnotę polityczna, na co wskazuje także przypadek stabilnych demokracji zachodnioeuropejskich, realizujących po drugiej wojnie światowej ideały państwa opiekuńczego. Może odegrać taką rolę także obecnie, kiedy ruchy takie jak Occupy Wall Street czy Oburzeni w Europie wyrażają bunt przeciw nierównościom.

22 Ibidem, s. 268.

${ }^{23}$ Ibidem, s. 272. 
Należy ponadto zauważyć, że współcześnie idea solidarności może być realizowana w wielu wymiarach: na poziomie lokalnym, gdzie jest najszersza wiedza o konkretnej sytuacji najsłabszych obywateli; na poziomie państwowym, gdzie istnieja instytucje mające za cel spójność wspólnoty politycznej (na przykład pod względem ekonomicznym czy kulturowym) oraz na poziomie ponadpaństwowym - aby zniwelować zagrożenia, jakie niesie ze sobą narastajace rozwarstwienie ekonomiczne między państwami. 